\title{
Expression of urotensin II and its receptor in human lung adenocarcinoma A549 cells and the effect of urotensin II on lung adenocarcinoma growth in vitro and in vivo
}

\author{
YU-QING WU ${ }^{3 *}$, ZHENG SONG ${ }^{2 *}$, CHENG-HUA ZHOU ${ }^{2}$, SHU-HUA XING ${ }^{2}$, \\ DONG-SHENG PEI ${ }^{1}$ and JUN-NIAN ZHENG ${ }^{1}$ \\ ${ }^{1}$ Laboratory of Biological Cancer Therapy, ${ }^{2}$ Department of Pharmacology, and ${ }^{3}$ Jiangsu Province Key Laboratory \\ of Anesthesiology, Xuzhou Medical College, Huaihai Road 84, Xuzhou 221002, Jiangsu, P.R. China
}

Received April 13, 2010; Accepted June 10, 2010

DOI: $10.3892 /$ or 00000970

\begin{abstract}
Urotensin II (UII), originally identified from fish urophysis, is a potent vasoactive peptide and an endogenous ligand for an orphan $\mathrm{G}$ protein-coupled receptor GPR14, now named as urotensin II receptor (UT-R). In this study, we investigated the mRNA and protein expressions of UII and its receptor (UT-R) in human lung adenocarcinoma A549 cells, and the effect of exogenous UII on the proliferation of A549 cells in vitro and in vivo. Reverse transcription-polymerase chain reaction (RT-PCR) and Western blot analysis showed that both mRNAs and proteins of UII and UT-R were obviously expressed in human lung adenocarcinoma A549 cells. Immunohistochemical analysis showed that UII peptide was mainly expressed in the cytoplasm, and UT-R protein was expressed on the cytomembrane and also in the cytoplasm. 3-[4,5-dimethylthiazol-2yl]-2,5-diphenyl tetrazolium bromide (MTT) analysis demonstrated that treatment with different concentrations of human UII $\left(10^{-9}, 10^{-8}, 10^{-7}\right.$ and $\left.10^{-6} \mathrm{M}\right)$ for $48 \mathrm{~h}$ significantly increased the number of A549 cells. The effect of UII at the concentration of $10^{-7} \mathrm{M}$ on the proliferation of A549 cells is most pronounced. Nude mice bearing human lung adenocarcinoma A549 cells treated with UII showed a significant increase in tumor volume and tumor weight compared with control group. These findings suggest that UII may contribute to the pathogenesis of human lung adenocarcinoma as an autocrine/paracrine growth stimulating factor.
\end{abstract}

Correspondence to: Dr Jun-Nian Zheng, Laboratory of Biological Cancer Therapy, Xuzhou Medical College, Huaihai Road 84, Xuzhou 221002, Jiangsu, P.R. China

E-mail: chzhou77@126.com

${ }^{*}$ Contributed equally

Key words: urotensin II, lung adenocarcinoma, nude mice, A549 cells

\section{Introduction}

Urotensin II (UII), a 'somatostatin-like' cyclic peptide, was originally isolated from the fish urophysis (1). Subsequently, the cDNAs encoding UII in human (2), monkey (3), mouse and rat (4) were cloned. It has been shown that UII is an endogenous ligand for the orphan $G$ protein-coupled receptor GRP14 (5), which is now termed as urotensin II receptor (UT-R) (6). UII has been demonstrated to exert a profound vascular effect including vasoconstrictor activity $(5,7,8)$ and vasodilator activity $(9,10)$ dependent on the anatomic sites and the species studied. In addition, UII has a positive inotropic effect (11) and stimulates the proliferation of vascular smooth muscle cells (12-14). There is also evidence for UII to regulate pancreatic function by inhibition insulin release (15).

Recent studies have revealed that UII plays an important role in the pathogenesis of some tumors. Takahashi et al (16) showed that UII and UT-R are expressed in glioblastoma cell line T98G, neuroblastoma cell line IMR32, choriocarcinoma cell line BeWo, adrenocortical carcinoma cell line SW-13, colorectal carcinoma cell line DLD-1, and cervical carcinoma cell line HeLa. UII and UT-R mRNA are also expressed in adrenal tumor $(17,18)$, renal carcinoma (19), and pheochromocytoma $(20,21)$. Furthermore, SW-13 cells has been demonstrated to secrete UII (16). These findings suggest the potential role of UII in tumor growth as an autocrine/paracrine growth factor. Indeed, UII has been shown to have mitogenic effects on some tumor cells including SW-13 cells (18), renal cell carcinoma VMRC-RCW cells (18), and human pheochromocytoma cells (20). There has been, however, no report on the expression of UII and UT-R in human lung adenocarcinoma.

In the present study, we investigated the mRNA and protein expressions of UII and UT-R in human lung adenocarcinoma A549 cells, and the effect of exogenous UII on the proliferation of A549 cells in vitro and in vivo.

\section{Materials and methods}

Materials. Human UII and antibodies for UII and UT-R were obtained from Sigma Chemical Co. (St. Louis, MO, USA). 
F-12 Ham's Kaighn's Modification (F-12K) medium was purchased from M\&C Gene Technology Co. (Beijing, China). Fetal bovine serum (FBS) was purchased from Gibco-BRL (Auckland, New Zealand). 3-[4,5-dimethylthiazol-2-yl]-2,5-diphenyl tetrazolium bromide (MTT) was from Amresco (Solon, OH, USA). RNAsimple Total RNA Kit, M-MLV reverse transcriptase, oligo (dT) and Taq DNA polymerase were from Tiangen Biotech Co., Ltd., Beijing, China). Antibody for B-actin was from Zhongshan Goldenbridge Biotechnology Co., Ltd. (Beijing, China). Horseradish peroxidase-coupled goat anti-rabbit IgG was purchased from Boster Biological Technology, Ltd. (Wuhan, China). BCA Protein Assay Kit was obtained from Pierce Co. (Rockford, IL, USA). BCIP/NBT Color Development Substrate was from Promega Co. (Madison, WI, USA).

Cell culture. Human lung adenocarcinoma cell line A549 was purchased from the American Tissue Type Collection (Manassas, VA). Cells were grown in F-12K medium containing $10 \% \mathrm{FBS}$ and $1 \%$ penicillin/streptomycin in a humidified $37^{\circ} \mathrm{C}$ incubator with an atmosphere of $95 \%$ air and $5 \% \mathrm{CO}_{2}$.

Semi-quantitative RT-PCR for UII and UT-R mRNAs in A549 cells. Total RNA was extracted from cultured A549 cells using RNAsimple Total RNA Kit according to the manufacturer's instruction. The quality of isolated RNA was examined by the ratio of A260/A280 and gel electrophoresis. Total RNA $(5 \mu \mathrm{g})$ was denatured at $70^{\circ} \mathrm{C}$ for $5 \mathrm{~min}$ and reverse-transcription was performed at $42^{\circ} \mathrm{C}$ for $50 \mathrm{~min}$ in a reaction mixture $(20 \mu 1)$ containing RNase inhibitor $20 \mathrm{U}$, M-MLV reverse transcriptase $200 \mathrm{U}$, each of dNTP mixture $2.5 \mathrm{mM}$, oligo (dT) primer $10 \mu \mathrm{M}$. The reaction was stopped by heating at $95^{\circ} \mathrm{C}$ for $5 \mathrm{~min}$, and the reaction mixture was stored at $-20^{\circ} \mathrm{C}$ until PCR analysis. Primers for UII were 5'-CTT TCA ACT CTC AGC ACC TCA T-3' (sense) and 5'-CCT AGT TTT TCT CCA CAC TGT T-3' (antisense) with a PCR product of $385 \mathrm{bp}$ (16). PCR was performed with $10.5 \mu 1$ of the reaction mixture in a $25-\mu 1$ reaction system containing $10.5 \mathrm{mM}$ Tris- $\mathrm{HCl}(\mathrm{pH} 8.3), 53 \mathrm{mM} \mathrm{KCl}, 1.6 \mathrm{mM}$ $\mathrm{MgCl}_{2}, 0.3 \mathrm{mM}$ of each dNTP, $10 \mu \mathrm{M}$ of each primer, and 1.32 U Taq DNA polymerase. After heating at $94^{\circ} \mathrm{C}$ for $3 \mathrm{~min}$, denaturation, annealing and elongation were carried out at $94^{\circ} \mathrm{C}$ for $15 \mathrm{sec}, 58^{\circ} \mathrm{C}$ for $60 \mathrm{sec}$ and $72^{\circ} \mathrm{C}$ for $90 \mathrm{sec}$, and the reactions were repeated 40 cycles, followed by $72^{\circ} \mathrm{C}$ for $5 \mathrm{~min}$. Water $(10.5 \mu \mathrm{l})$ was used instead of the reaction mixture in a negative control.

RT-PCR analysis for UT-R and glyceraldehyde-3-phosphate dehydrogenase (GAPDH) mRNAs was performed as previously reported (16). Primers for UT-R were 5'-CCC CAA CGC AAC CCT CAA CA-3' (sense) and 5'-GGT CGC GGT AGT TCC TGG TGA-3' (antisense) with a PCR product of 893 bp. Primers for GAPDH were 5'-GGT CGG AGT CAA CGG ATT TG-3' (sense) and 5'-ATG AGG TCC ACC ACC CTG TT-3' (antisense) with a PCR product of $969 \mathrm{bp}$. One $\mu 1$ of water was used instead of the reaction mixture in a negative control.

PCR products were subsequently electrophoresed on $1.5 \%$ agarose gels, stained with ethidium bromide, and visualized under ultraviolet light. Intensities of UII and UT-R were standardized to that of GAPDH, which was used as an internal standard.

Immunocytochemistry for UII and UT-R proteins in A549 cells. Cell monolayers grown on glass coverslips were fixed in $4 \%$ paraformaldehyde for $30 \mathrm{~min}$ at room temperature. Endogenous peroxidase activity was quenched by incubation with $0.5 \% \mathrm{H}_{2} \mathrm{O}_{2}$ for $30 \mathrm{~min}$. After preincubation with $5 \%$ bovine serum albumin for $30 \mathrm{~min}$ to prevent non-specific staining, the cells were incubated with antibody of UII or UT-R for $1 \mathrm{~h}$ at $37^{\circ} \mathrm{C}$. Antibody dilution buffer was used as negative controls instead of primary antibodies. The cells were then incubated with horseradish peroxidase-coupled goat anti-rabbit $\mathrm{IgG}$ for $20 \mathrm{~min}$ followed by incubation with streptavidin biotinylated complex for $40 \mathrm{~min}$ at $37^{\circ} \mathrm{C}$. The peroxidase was visualized by incubation with $3,3^{\prime}-$ diaminobenzidine (DAB) in dark for $15 \mathrm{~min}$. The cells were counterstained with hematoxylin, dehydrated, and observed under light microscope. Positive staining was indicated by brownish deposits.

Western blot analysis for UII and UT-R proteins in A549 cells. A549 cells were lysed in ice-cold RIPA lysis buffer containing phenylmethylsulfonyl fluoride (PMSF). The lysates were centrifuged at $12,000 \mathrm{x}$ g for $8 \mathrm{~min}$ at $4^{\circ} \mathrm{C}$. Supernatants were used immediately or stored at $-70^{\circ} \mathrm{C}$. Protein concentrations were determined by a BCA Protein Assay Kit. Sodium dodecyl sulfate-polyacrylamide gel electrophoresis (SDS-PAGE) sample loading buffer was used as negative control. The protein sample was separated on a $12 \%$ SDS-polyacrylamide gel and transferred onto a nitrocellulose membrane by electrotransfer. Membranes were blocked with 5\% non-fat milk powder in Tris-buffered saline (TBS) for $1 \mathrm{~h}$ at room temperature, and then incubated with specific antibodies at $4^{\circ} \mathrm{C}$ overnight. Membranes were subsequently washed three times and incubated in horseradish peroxidase-coupled anti-rabbit IgG for $1 \mathrm{~h}$. Immunoreactive bands were visualized with BCIP/NBT Color Development Substrate.

MTT analysis for the proliferation of A549 cells. A549 cells were seeded into 96-well culture plates at a density of $6 \times 10^{3}$ cells/well. After $24 \mathrm{~h}$, the medium was replaced by F-12K medium containing $0.5 \%$ FBS to make the cells quiescent for $24 \mathrm{~h}$. Cells were then incubated with or without UII $\left(10^{-9}, 10^{-8}\right.$, $\left.10^{-7}, 10^{-6} \mathrm{M}\right)$ for $48 \mathrm{~h}$. Then a volume of $20 \mu \mathrm{lof} 5 \mathrm{mg} / \mathrm{ml}$ MTT was added to each well and incubated for $4 \mathrm{~h}$ at $37^{\circ} \mathrm{C}$. Formazan crystals were dissolved in $150 \mu \mathrm{l}$ of DMSO and the absorbance was measured at a wavelength of $490 \mathrm{~nm}$ with a microplate reader (CliniBio 128C, ASYS Hitech GmbH, Austria).

In vivo tumor xenograft model. Athymic (nu/nu) male BALB/c nude mice were obtained from Shanghai Laboratory Animals Center of the Chinese Academy of Sciences (Shanghai, China), housed under pathogen-free conditions with a $12 \mathrm{~h}$ light $/ 12 \mathrm{~h}$ dark schedule, and fed with an autoclaved diet ad libitum. A549 cells were harvested by trypsinization and resuspended in F-12K medium. To establish A549 tumor xenografts in mice, 6-week old athymic mice 


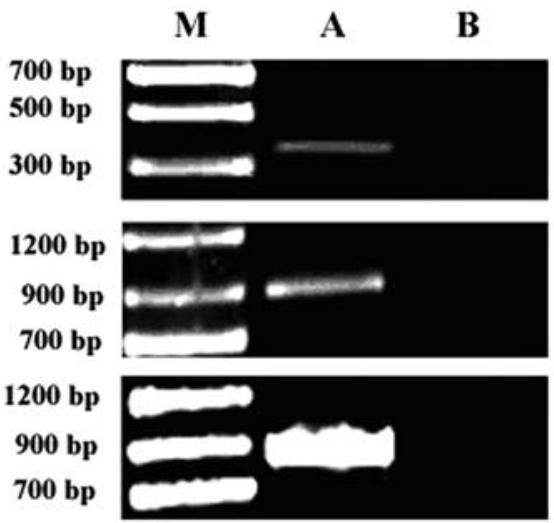

UII

UT-R

GAPDH

Figure 1. RT-PCR for urotensin II (UII) and urotensin II receptor (UT-R) mRNAs in human lung adenocarcinoma cell line A549. Total RNA was extracted from A549 cells and then subjected to reverse transcription. PCR products were subsequently electrophoresis on $1.5 \%$ agarose gels and stained with ethidium bromide. The expression of GAPDH mRNA was used as an internal standard. Lane A, the expression of UII and UT-R mRNAs in A549 cells; lane B, negative control. M, marker.

were injected s.c. in the upper right flank with $5 \times 10^{6}$ lung adenocarcinoma A549 cells suspended in $200 \mu 1$ of cold Matrigel (BD Biosciences, Bedford, MA). After 10 days, the mice were separated randomly into control group that only received saline and UII-treated groups that were administered UII $\left(10^{-7} \mathrm{M}\right)$ i.p. daily. On day 28 of the injection, the mice were humanely sacrificed and the tumors were removed and weighed. The tumor volume (V) was calculated using the formula $\mathrm{V}=1 / 2 \mathrm{x}$ length $\mathrm{x}$ (width) $)^{2}(22)$. The mouse studies were approved by the Animal Care and Use Committee of Xuzhou Medical College.

Statistical analysis. Values are given as the mean \pm SD. Statistical differences between mean values were determined using one-way ANOVA. $\mathrm{P}<0.05$ was considered statistically significant.

\section{Results}

Semi-quantitative RT-PCR for UII and UT-R mRNAs in A549 cells. The results of RT-PCR analysis demonstrated that both UII and UT-R mRNAs were expressed in human lung adenocarcinoma cell line A549, with UII mRNA expressed at quantitatively lower levels than UT-R (Fig. 1, lane A). Negative control showed no detectable band, which showed no evidence for either contamination or the presence of genomic DNA (Fig. 1, lane B).

Immunocytochemistry for UII and UT-R proteins in A549 cells. For immunocytochemistry, A549 cells were immunostained with specific antibody to UII or UT-R. The results showed that both UII and UT-R peptides were expressed in A549 cells. UII immunoreactivity was mainly detected in the cytoplasm (Fig. 2A). Positive staining for UT-R protein was localized on the cell membrane and also in the cytoplasm
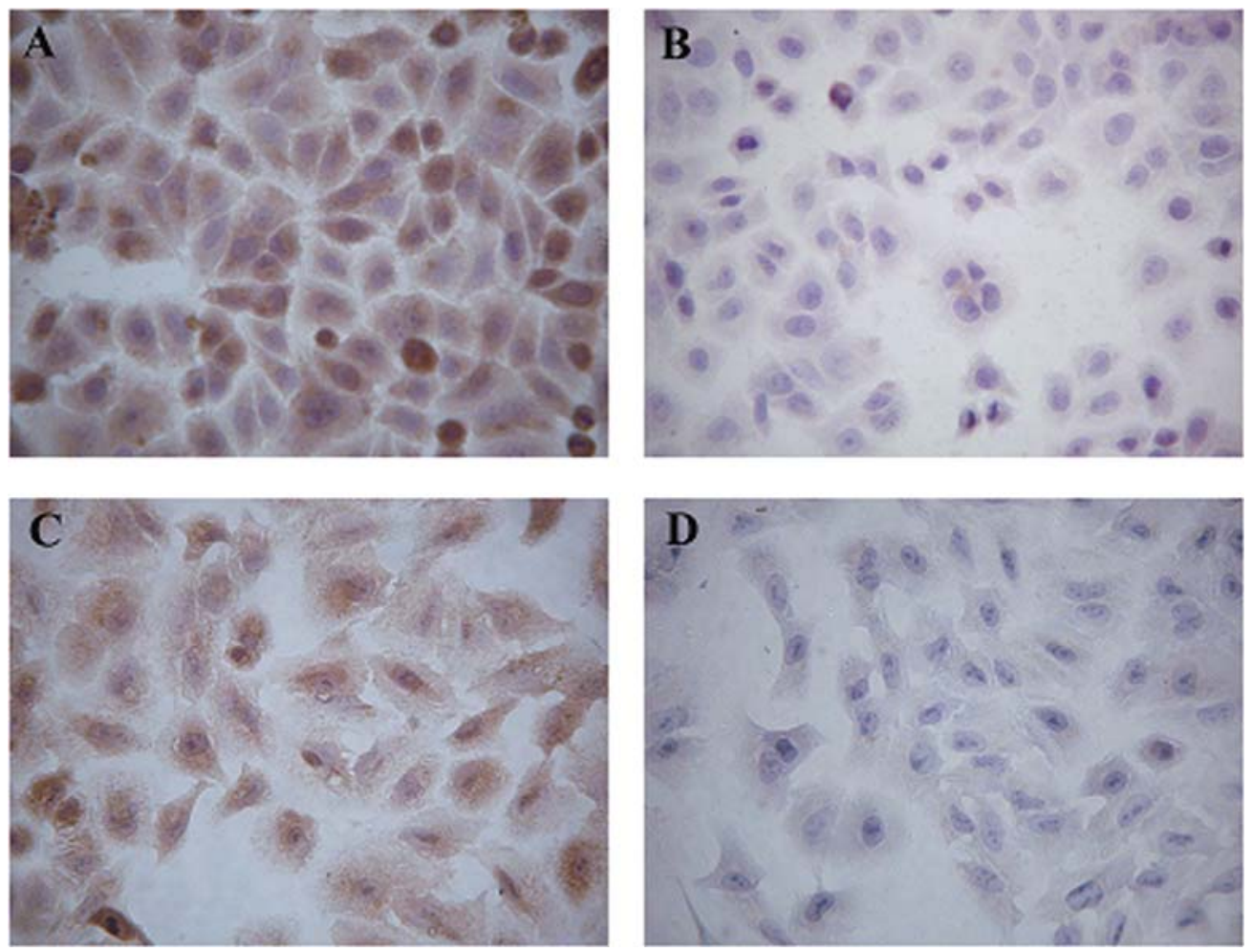

Figure 2. Immunocytochemistry for urotensin II (UII) and urotensin II receptor (UT-R) proteins in human lung adenocarcinoma cell line A549. Immunoreactivity appears brown as a result of DAB colorimetric reaction. (A) A549 cells stained with rabbit anti-UII antibody. (B) Negative control stained by antibody dilution buffer instead of UII antibody. (C) A549 cells stained with rabbit anti-UT-R antibody. (B) Negative control stained by antibody dilution buffer instead of UT-R antibody (magnification, x400). 
M A $\mathbf{B}$

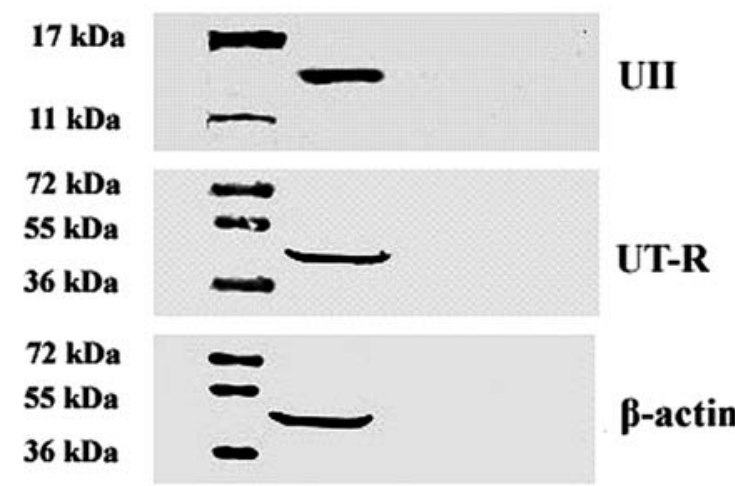

Figure 3. Western blot analysis for urotensin II (UII) and urotensin II receptor (UT-R) proteins in human lung adenocarcinoma cell line A549. The lysates of A549 cells were subjected to SDS-PAGE and analyzed by Western blot analysis. Lane A, the expression of UII and UT-R proteins in A549 cells; lane B, negative control. M, prestained protein molecular weight marker.

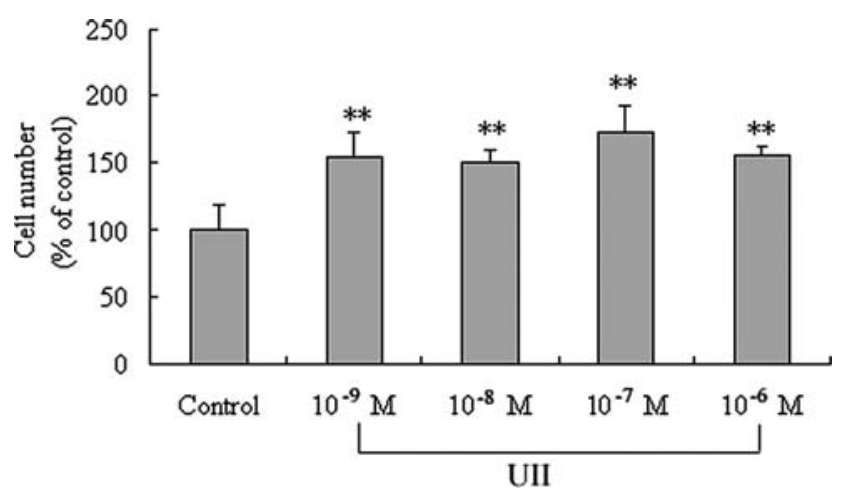

Figure 4. Effect of urotensin II (UII) on the proliferation of human lung adenocarcinoma A549 cells. Growth-arrested A549 cells were stimulated with various concentrations of UII $\left(10^{-9}, 10^{-8}, 10^{-7}, 10^{-6} \mathrm{M}\right)$ for $48 \mathrm{~h}$, and the cell proliferation was assayed by MTT. Data are expressed as mean $\pm \mathrm{SD}$. $(\mathrm{n}=6) .{ }^{* *} \mathrm{P}<0.01$ vs. control cells.
(Fig. 2C). Negative controls stained by antibody dilution buffer instead of primary antibodies revealed no positive immunostaining (Fig. 2B and D).

Western blot analysis for UII and UT-R proteins in A549 cells. Subsequently, to validate our findings, we further investigated the expression of UII and UT-R proteins in A549 cells by Western blot analysis. The results showed that a band corresponding to the size of UII precursor ( $\sim 14 \mathrm{kDa})$ was detected in A549 cells (Fig. 3, lane A). The expression of UT-R with the expected molecular weight of about $43 \mathrm{kDa}$ was also detected in A549 cells (Fig. 3, lane A). No band was found in negative control, showing the specificity of the antibodies used (Fig. 3, lane B). The band illustrated in Fig. 3 represents the majority of the results obtained and could be reproduced on at least four occasions.

Effect of UII on the proliferation of A549 cells. To evaluate whether UII can regulate the proliferation of A549 cells, cells were stimulated with various concentrations of UII $\left(10^{-9}, 10^{-8}, 10^{-7}, 10^{-6} \mathrm{M}\right)$ for $48 \mathrm{~h}$, and the proliferative activity of A549 cells was determined by MTT. As shown in Fig. 4, compared with control cells, UII significantly stimulated the proliferation of A549 cells with the maximal effect at $10^{-7} \mathrm{M}$ (1.72-fold).

Effect of UII on lung adenocarcinoma growth in a tumor xenograft model. To test the effect of UII on lung adenocarcinoma growth in the xenograft model, nude mice bearing human lung adenocarcinoma A549 cells were treated with UII or saline daily. When the experiment terminated, the control group had an average volume of $622 \mathrm{~mm}^{3}$, whereas UII group showed a significant increase in tumor volume to $877 \mathrm{~mm}^{3}(\mathrm{P}<0.05$, Fig. 5A and $\mathrm{B})$. In addition, the average tumor weight in the control group was $0.76 \mathrm{~g}$, and in the UII-treated group tumor weight was increased to $1.04 \mathrm{~g}$ $(\mathrm{P}<0.05$, Fig. 5A and $\mathrm{C})$.

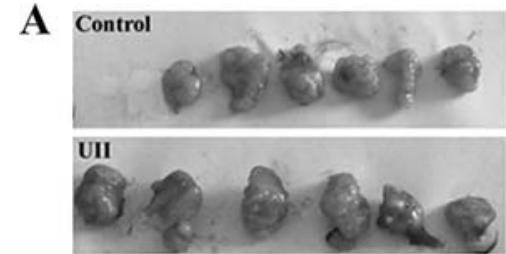

B

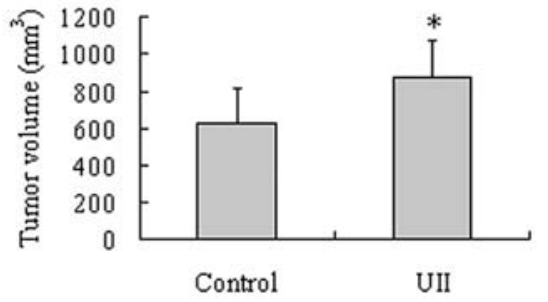

C

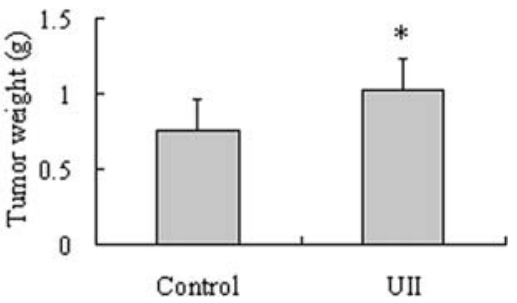

Figure 5. Effect of urotensin II (UII) on lung adenocarcinoma growth in a tumor xenograft model. Six-week old nude mice were injected s.c. with lung adenocarcinoma A549 cells. After 10 days, the mice were separated randomly into control group that only received saline and UII-treated group that were administered UII $\left(10^{-7} \mathrm{M}\right)$ i.p. daily. On day 28 of the injection, the mice were humanely sacrificed and the tumors were removed and weighed. (A) Tumors excised from nude mice xenograft models. (B) The tumor volume (V) in control group and UII group, calculated using the formula $\mathrm{V}=1 / 2 \mathrm{x}$ length $\mathrm{x}$ (width) $)^{2}$. (C) The tumor weight in control group and UII group. Data are expressed as mean $\pm \mathrm{SD}$ ( $\mathrm{n}=6$ ). ${ }^{*} \mathrm{P}<0.05$ vs. control group. 


\section{Discussion}

In the present study, we demonstrated for the first time that both UII and UT-R were expressed in human lung adenocarcinoma A549 cells using RT-PCR, immunocytochemistry and Western blot analysis. In addition, our results showed that exogenous UII could stimulate the proliferation of A549 cells in vitro and promote the tumor growth in a nude mice xenograft model.

UII was identified initially as a neuropeptide restrictly expressed in the central nervous system (5). More detailed studies have demonstrated that both UII and UT-R are co-expressed in cardiovascular, renal and endocrine tissues $(5,23)$. Recently, UII and UT-R have been identified in some tumor tissues including adrenal tumor $(17,18)$, renal carcinoma (19), and pheochromocytoma (20). In addition, the expression of UII and UT-R has also been found in some tumor cell lines, such as glioblastoma cell line T98G, neuroblastoma cell line IMR32, choriocarcinoma cell line BeWo, adrenocortical carcinoma cell line SW-13, colorectal carcinoma cell line DLD-1, and cervical carcinoma cell line HeLa (16). Moreover, it has been shown that lung tumors express some neuropeptides, vasoactive peptides and their receptors, for example, endothelin and gastrin-releasing peptide (24-26), which in turn promote the tumor growth as the autocrine/paracrine growth stimulating factors. However, there has been no report on the expression of UII and UT-R in human lung adenocarcinoma.

In the present study, both UII and UT-R mRNAs were detected in human lung adenocarcinoma A549 cells by RT-PCR analysis. This is the first report that UII and UT-R mRNAs are stably expressed in A549 cells. To further validate our findings, immunohistochemistry and Western blot analysis were performed to determine the expression of UII and UT-R proteins. Consistent with the results of RT-PCR, the expression of UII precursor peptide and UT-R protein were detected in human lung adenocarcinoma A549 cells. Immunohistochemical analysis also showed that UII peptide was mainly expressed in the cytoplasm, and UT-R protein was obviously expressed on the cytomembrane and also in the cytoplasm. These results implied that UII/UT-R system may mediate important signals for lung adenocarcinoma progression through autocrine/paracrine mechanisms.

The proliferation of tumor cells is dependent on growth stimulating factors, such as platelet-derived growth factor (PDGF), angiotensin and endothelin (27-29). The mitogenic effect of UII have been reported in a variety of cells, including aorta smooth muscle cells $(12,30)$, cardiomyocytes (31), and fibroblasts (32). Recent studies have demonstrated that UII promotes the proliferation of some tumor cells, such as SW-13 cells (18), renal cell carcinoma VMRC-RCW cells (18), and human pheochromocytoma cells (20). Our present study showed that UII could also stimulate the proliferation of human lung adenocarcinoma A549 cells and increase tumor volume and tumor weight in a nude mice xenograft model, supporting the possibility that UII is involved in lung adenocarcinoma progression as a growth stimulating factor. In addition, our results indicated that the effect of UII at the concentration of $10^{-7} \mathrm{M}$ on the proliferation of A549 cells is most pronounced. This is partly consistent with the previous study showing that a higher concentration of UII had no significant effect on the number of renal cell carcinoma VMRC-RCW cells, probably due to cytotoxic effects (18). In our study, $10^{-6} \mathrm{M}$ UII may have mild cytotoxicity to A549 cells. Inconsistent with our results, the cytotoxicity of UII produced at the concentration of $10^{-7} \mathrm{M}$ in VMRCRCW cells (18). This discrepancy could be explained by the difference of cell types and experimental conditions.

Several studies have shown that the mitogenic effect of UII are associated with mitogen-activated protein kinases (MAPK), protein kinase C (PKC), $\mathrm{Ca}^{2+}$, RhoA/Rho-kinase in smooth muscle cells and renal epithelial cells $(12,33,34)$. Further studies are needed to investigate the signal transduction pathways for the mitogenic effect of UII on human lung adenocarcinoma A549 cells. In addition, UII has been shown to have synergistic effect with some other mitogens such as oxidized-low density lipoprotein and serotonin $(13,14,35)$. It remains to be further studied whether UII has synergistic effect with other tumor growth stimulating factors, such as PDGF, angiotensin and endothelin.

In conclusion, our present study demonstrated for the first time that both UII and UT-R were expressed in human lung adenocarcinoma A549 cells, and UII could stimulate the proliferation of A549 cells and promote the tumor growth in a nude mice xenograft model. These findings suggest that UII may contribute to the pathogenesis of human lung adenocarcinoma as an autocrine/paracrine growth stimulating factor. In clinic, the results of the present study provide a potential therapeutic target for human lung adenocarcinoma.

\section{Acknowledgements}

This study was supported by Natural Science Foundation of the Jiangsu Higher Education Institutions of China (No. 08KJD310010); President Special Foundation of Xuzhou Medical College (No. 08KJZ05); and Open Fund of Laboratory of Biological Cancer Therapy, Xuzhou Medical College (No. C0804).

\section{References}

1. Pearson D, Shively JE, Clark BR, Geschwind II, Barkley M, Nishioka RS and Bern HA: Urotensin II: a somatostatin-like peptide in the caudal neurosecretory system of fishes. Proc Natl Acad Sci USA 77: 5021-5024, 1980.

2. Coulouarn Y, Lihrmann I, Jegou S, et al: Cloning of the cDNA encoding the urotensin II precursor in frog and human reveals intense expression of the urotensin II gene in motoneurons of the spinal cord. Proc Natl Acad Sci USA 95: 15803-15808, 1998.

3. Elshourbagy NA, Douglas SA, Shabon U, et al: Molecular and pharmacological characterization of genes encoding urotensinII peptides and their cognate G-protein-coupled receptors from the mouse and monkey. Br J Pharmacol 136: 9-22, 2002.

4. Coulouarn Y, Jégou S, Tostivint H, Vaudry H and Lihrmann I: Cloning, sequence analysis and tissue distribution of the mouse and rat urotensin II precursors. FEBS Lett 457: 28-32, 1999.

5. Ames RS, Sarau HM, Chambers JK, et al: Human urotensin-II is a potent vasoconstrictor and agonist for the orphan receptor GPR14. Nature 401: 282-286, 1999.

6. Davenport AP and Maguire JJ: Urotensin II: fish neuropeptide catches orphan receptor. Trends Pharmacol Sci 21: 80-82, 2000.

7. Camarda V, Rizzi A, Calò G, et al: Effects of human urotensin II in isolated vessels of various species; comparison with other vasoactive agents. Naunyn Schmiedebergs Arch Pharmacol 365: 141-149, 2002. 
8. Douglas SA, Sulpizio AC, Piercy V, et al: Differential vasoconstrictor activity of human urotensin-II in vascular tissue isolated from the rat, mouse, dog, pig, marmoset and cynomolgus monkey. Br J Pharmacol 131: 1262-1274, 2000.

9. Katano Y, Ishihata A, Aita T, Ogaki T and Horie T: Vasodilator effect of urotensin II, one of the most potent vasoconstricting factors, on rat coronary arteries. Eur J Pharmacol 402: R5-R7, 2000.

10. Gardiner SM, March JE, Kemp PA, Davenport AP and Bennett T: Depressor and regionally-selective vasodilator effects of human and rat urotensin II in conscious rats. Br J Pharmacol 132: 1625-1629, 2001.

11. Russell FD, Molenaar P and O'Brien DM: Cardiostimulant effects of urotensin-II in human heart in vitro. Br J Pharmacol 132: 5-9, 2001.

12. Sauzeau V, Le Mellionnec E, Bertoglio J, Scalbert E, Pacaud P and Loirand G: Human urotensin II-induced contraction and arterial smooth muscle cell proliferation are mediated by RhoA and Rho-kinase. Circ Res 88: 1102-1104, 2001.

13. Watanabe T, Pakala R, Katagiri T and Benedict CR: Synergistic effect of urotensin II with mildly oxidized LDL on DNA synthesis in vascular smooth muscle cells. Circulation 104: 16-18, 2001.

14. Watanabe T, Pakala R, Katagiri $\mathrm{T}$ and Benedict CR: Synergistic effect of urotensin II with serotonin on vascular smooth muscle cell proliferation. J Hypertens 19: 2191-2196, 2001 .

15. Silvestre RA, Rodríguez-Gallardo J, Egido EM and Marco J: Inhibition of insulin release by urotensin II, a study on the perfused rat pancreas. Horm Metab Res 33: 379-381, 2001.

16. Takahashi K, Totsune K, Murakami O and Shibahara S: Expression of urotensin II and urotensin II receptor mRNAs in various human tumor cell lines and secretion of urotensin II-like immunoreactivity by SW-13 adrenocortical carcinoma cells. Peptides 22: 1175-1179, 2001.

17. Morimoto R, Satoh F, Murakami O, et al: Immunolocalization of urotensin II and its receptor in human adrenal tumors and attached non-neoplastic adrenal tissues. Peptides 29: 873-880, 2008.

18. Takahashi K, Totsune K, Murakami O, Arihara Z, Noshiro T, Hayashi Y and Shibahara S: Expression of urotensin II and its receptor in adrenal tumors and stimulation of proliferation of cultured tumor cells by urotensin II. Peptides 24: 301-306, 2003.

19. Shenouda A, Douglas SA, Ohlstein EH and Giaid A: Localization of urotensin-II immunoreactivity in normal human kidneys and renal carcinoma. J Histochem Cytochem 50: 885-889, 2002

20. Zeng ZP, Liu GQ, Li HZ, et al: The effects of urotensin-II on proliferation of pheochromocytoma cells and mRNA expression of urotensin-II and its receptor in pheochromocytoma tissues. Ann N Y Acad Sci 1073: 284-289, 2006.

21. Giuliani L, Lenzini L, Antonello M, et al: Expression and functional role of urotensin-II and its receptor in the adrenal cortex and medulla: novel insights for the pathophysiology of primary aldosteronism. J Clin Endocrinol Metab 94: 684-690, 2009.

22. Shi J, Zheng D, Liu Y, Sham MH, Tam P, Farzaneh F and $\mathrm{Xu}$ R: Overexpression of soluble TRAIL induces apoptosis in human lung adenocarcinoma and inhibits growth of tumor xenografts in nude mice. Cancer Res 65: 1687-1692, 2005.
23. Matsushita M, Shichiri M, Imai T, Iwashina M, Tanaka $H$, Takasu N and Hirata Y: Co-expression of urotensin II and its receptor (GPR14) in human cardiovascular and renal tissues. J Hypertens 19: 2185-2190, 2001.

24. Deprez-Roy I, Coge F, Bertry L, Galizzi JP, Feletou M, Vanhoutte PM and Canet E: Endothelin-1 pathway in human alveolar epithelial cell line A549 and human umbilical vein endothelial cells. Acta Pharmacol Sin 21: , 2000.

25. Ahmed SI, Thompson J, Coulson JM and Woll PJ: Studies on the expression of endothelin, its receptor subtypes, and converting enzymes in lung cancer and in human bronchial epithelium. Am J Respir Cell Mol Biol 22: 422-431, 2000.

26. Uchida K, Kojima A, Morokawa N, et al: Expression of progastrin-releasing peptide and gastrin-releasing peptide receptor mRNA transcripts in tumor cells of patients with small cell lung cancer. J Cancer Res Clin Oncol 128: 633-640, 2002.

27. Lokker NA, Sullivan CM, Hollenbach SJ, Israel MA and Giese NA: Platelet-derived growth factor (PDGF) autocrine signaling regulates survival and mitogenic pathways in glioblastoma cells: evidence that the novel PDGF-C and PDGF-D ligands may play a role in the development of brain tumors. Cancer Res 62: 3729-3735, 2002.

28. Imai N, Hashimoto T, Kihara M, et al: Roles for host and tumor angiotensin II type 1 receptor in tumor growth and tumorassociated angiogenesis. Lab Invest 87: 189-198, 2007.

29. Asham E, Shankar A, Loizidou M, et al: Increased endothelin-1 in colorectal cancer and reduction of tumour growth by ET(A) receptor antagonism. Br J Cancer 85: 1759-1763, 2001.

30. Tsai CS, Loh SH, Liu JC, Lin JW, Chen YL, Chen CH and Cheng TH: Urotensin II-induced endothelin-1 expression and cell proliferation via epidermal growth factor receptor transactivation in rat aortic smooth muscle cells. Atherosclerosis 206: 86-94, 2009.

31. Liu JC, Chen CH, Chen JJ and Cheng TH: Urotensin II induces rat cardiomyocyte hypertrophy via the transient oxidization of Src homology 2-containing tyrosine phosphatase and transactivation of epidermal growth factor receptor. Mol Pharmacol 76: 1186-1195, 2009.

32. Zhang Y, Li Y, Wei R, et al: Urotensin II is an autocrine/ paracrine growth factor for aortic adventitia of rat. Regul Pept 151: 88-94, 2008.

33. Matsushita M, Shichiri M, Fukai N, Ozawa N, Yoshimoto T, Takasu $\mathrm{N}$ and Hirata Y: Urotensin II is an autocrine/paracrine growth factor for the porcine renal epithelial cell line, LLCPK1. Endocrinology 144: 1825-1831, 2003.

34. Onan D, Pipolo L, Yang E, Hannan RD and Thomas WG: Urotensin II promotes hypertrophy of cardiac myocytes via mitogen-activated protein kinases. Mol Endocrinol 18: 2344$2354,2004$.

35. Watanabe T, Takahashi K, Kanome T, et al: Human urotensin-II potentiates the mitogenic effect of mildly oxidized low-density lipoprotein on vascular smooth muscle cells: comparison with other vasoactive agents and hydrogen peroxide. Hypertens Res 29: 821-831, 2006. 